\title{
Degradation and leaching of Napropamide in BRIS soil amended with chicken dung and palm oil mill effluent.
}

\begin{abstract}
The degradation and leaching of napropamide were compared between Beach Ridges Interspersed with Swales (BRIS) soil samples, and the same soil samples amended with 20mgha-1 of either chicken dung (CD) or palm oil mill effluent (POME). The effects of removing dissolved organic carbon (DOC) from the soil samples on napropamide degradation and leaching were also studied. The addition of CD and POME to BRIS soil increased the napropamide half-life values to 69 and 49.5 days, respectively. Sterilization of the soil samples resulted in partial inhibition of napropamide degradation in all soil samples. The half-lives of napropamide in BRIS soils receiving 0, 20, 100, and 200mgkg-1 of DOC derived from CD were 43, 46.2, 53.4, and 63 days, respectively. The napropamide half-lives in soil samples treated with $0,20,100$, and $200 \mathrm{mgkg}-1$ of DOC derived from POME were 43, 49.2, 57.7, and 69 days, respectively. However, in the sterilized soil samples, there were no significant effects of adding DOC derived from either CD or POME on napropamide halflives. Incorporating either CD or POME decreased napropamide leaching and total amounts of napropamide remained in the soil columns after two pore volumes of water has been leached were higher in the amended than the non-amended soil. The CD was more effective in decreasing napropamide leaching than the POME. There were no effects of DOC on napropamide leaching in all soil treatments.
\end{abstract}

Keyword: Napropamide; Degradation; Leaching; BRIS soil; Chicken dung; POME. 